\title{
Design and Modeling of a Solar Tower Chimney Effect Intended for Electrical Energy Production in Beni Abbes Site
}

\author{
Moussaoui Abdeljabar ${ }^{1}$, Mebarki Brahim², Sakhri Nasreddine ${ }^{3}$ \\ Draoui Belkacem ${ }^{4}$, Rahmani Lakhdar ${ }^{5}$ \\ Energarid Laboratory of Energy in Arid zones, Faculty of Technology. \\ TAHRI Mohammed University Bechar Algeria
}

\begin{abstract}
During these last years the current concerns about global warming and depletion of fossil resources have renewed the interest of the development of renewable energy in the electricity generation sector. Among them, solar energy holds a privileged position thanks to its technological progress and its associated costs comparatively low. The use of the technique based on the solar tower chimney effect has proved to be a promising approach for future applications. The work presented in this article is a feasibility study of a solar power plant chimney effect for the production of electrical energy to ensure the electricity needs of the entire Saharan region of Beni Abbes. The goal is to see the influence of certain parameters on the electrical output of the plant.
\end{abstract}

Keywords: Solar tower, solar energy, renewable energy, energy efficiency, electric power.

\begin{tabular}{|l|l|l|l|}
\hline \multicolumn{3}{|c|}{ NOMENCLATURE } \\
\hline Ac & Cross section of the chimney, $\mathrm{m}^{2}$ & $\mathrm{~T}_{\mathrm{amb}}$ & Ambient temperature, ${ }^{\circ} \mathrm{C}$ \\
\hline Acoll & Collector surface, $\mathrm{m}^{2}$ & $\mathrm{~T}_{\mathrm{o}}$ & Air temperature at the outlet of the manifold, ${ }^{\circ} \mathrm{C}$ \\
\hline $\mathrm{Cp}$ & Heat mass air $\mathrm{kJ} / \mathrm{kg} .{ }^{\circ} \mathrm{C}$ & $\mathrm{T}_{\text {ciel }}$ & Temperature sky, ${ }^{\circ} \mathrm{C}$ \\
\hline $\mathrm{D}_{\mathrm{c}}$ & Chimney diameter, $\mathrm{m}$ & $\mathrm{T}_{\mathrm{m}}$ & Average temperature in the collector, ${ }^{\circ} \mathrm{C}$ \\
\hline $\mathrm{D}_{\text {coll }}$ & Collector diameter, $\mathrm{m}$ & $\mathrm{TSV}$ & True solar time, $\mathrm{h}$ \\
\hline $\mathrm{E}_{\mathrm{S}}$ & Direct solar irradiance on an inclined surface, $\mathrm{W} / \mathrm{m}^{2}$ & $\mathrm{TSV}_{\mathrm{L}}$ & Solar time at sunrise, $\mathrm{h}$ \\
\hline $\mathrm{E}_{\mathrm{D}}$ & Diffuse irradiance on an inclined surface, $\mathrm{W} / \mathrm{m}^{2}$ & $\mathrm{TSV}_{\mathrm{c}}$ & Solar time at sunset, $\mathrm{h}$ \\
\hline $\mathrm{E}_{\mathrm{G}}$ & Global Illumination on an inclined surface, $\mathrm{W} / \mathrm{m}^{2}$ & $\mathrm{~V}_{\mathrm{c}}$ & Velocity of the air at the inlet of the chimney, $\mathrm{m} / \mathrm{s}$ \\
\hline $\mathrm{D}_{\mathrm{H}}$ & Diffuse irradiance on a horizontal surface, $\mathrm{W} / \mathrm{m}^{2}$ & $\mathrm{~V}_{\text {air }}$ & Speed of the ambient air, $\mathrm{m} / \mathrm{s}$ \\
\hline $\mathrm{G}_{\mathrm{H}}$ & Global illumination on a horizontal surface, $\mathrm{W} / \mathrm{m}^{2}$ & $\mathrm{q}$ & Air flow, Kg/s \\
\hline $\mathrm{g}$ & Acceleration of gravity, $\mathrm{m} / \mathrm{s}^{2}$ & $\rho_{\mathrm{coll}}$ & Density of air at outlet solar collector, $\mathrm{Kg} / \mathrm{m}^{3}$ \\
\hline $\mathrm{K}$ & Thermal conductance sensor, $\mathrm{W} / \mathrm{m}^{2} .{ }^{\circ} \mathrm{C}$ & $\eta_{0}$ & Optical efficiency of the collector \\
\hline $\mathrm{h}$ & Height of the sun, ${ }^{\circ}$ & $\eta_{\mathrm{coll}}$ & Collector performance \\
\hline $\mathrm{H}_{\mathrm{c}}$ & Height of the chimney, $\mathrm{m}$ & $\eta_{\mathrm{t}}$ & Turbine performance \\
\hline $\mathrm{n}$ & Day number in the year, & $\beta$ & Tilt Angle,,${ }^{\circ}$ \\
\hline $\mathrm{P}_{\mathrm{t} \text { max }}$ & Maximum turbine power, $\mathrm{kW}$ & $\omega$ & hour angle, ${ }^{\circ}$ \\
\hline $\mathrm{P}_{\mathrm{e}}$ & Electrical power delivered by the tower, $\mathrm{kW}$ & $\delta$ & declination of the sun, ${ }^{\circ}$ \\
\hline $\mathrm{Q}$ & Air heat gain in the collector, $\mathrm{kW}$ & $\varphi$ & latitude of the location considered \\
\hline $\mathrm{T}_{\text {abs }}$ & Temperature of the absorber, ${ }^{\circ} \mathrm{C}$ & $\mathrm{T}_{\mathrm{ct}}$ & Transparent cover Temperature, ${ }^{\circ} \mathrm{C}$ \\
\hline & & & \\
\hline
\end{tabular}

\section{Introduction}

World consumption in general and especially in Algeria is increasing. Much of the electrical energy consumed comes from fossil fuels (oil, natural gas, coal, etc ...) including the heavy use can lead to the depletion of these reserves and actually threatens the environment.

This threat is manifested mainly through pollution and global warming of the earth by greenhouse gases. Indeed, in 1992 at the Rio Conference and later in 1997, when the Kyoto Protocol, most states have made commitments to fight against the emission of greenhouse gases in order to contribute to the preservation of environmental and climatic balance.

From that moment, an unprecedented expansion of renewable energies worldwide appears first solar energy.

Solar energy is the biggest energy potential we have on Earth, constant very long term (several million years). Using the latter, particularly thermal energy for electricity generation is well suited for most of the arid and semi-arid because of the existence of a large solar energy potential in these regions, above $6 \mathrm{kWh} / \mathrm{m}^{2}$ on a sloping surface at the latitude of the place.

The solar chimney is one of the means of electricity production from solar energy. This in fact is only a chimney placed around the central chimney; a huge greenhouse is heated by the sun. The operation is based on a simple principle: hot air is lighter than cold air, it rises.

The air rushes in the greenhouse and is headed up by convection (at the top of the tower, air is colder than on the ground). The displacement of the air allowing the turbine located at the mouth of the chimney to 
generate electricity. The system produces electricity day and night through the residual heat from the ground and permanent temperature differential between the floor and the highest point of the tower.

Several experimental models have been successfully designed, built, and tested, to which structures differ from one installation to another. The first prototype of a central fireplace Solar is the Manzanares in Spain, compound of a metal tower $0.00125 \mathrm{~m}$ thick and a PVC roof collector. This prototype was built with the aim to collect measurements on the thermal and dynamic fields.

Fundamental studies of the Spanish system showed a brief discussion of the energy balance, design criteria and cost analysis of energy production and the system. Since then, considerable efforts have been made to size and estimate the energy efficiency of solar chimneys to demonstrate their feasibility and profitability. Solar and psychometric state of the air in southern Algeria are important to fully encourage the development of such facilities for the production of thermal or electric energy for various uses. The dimensions of the installation of a solar tower also have a great influence on the power produced. The figure below shows that the larger the size of the collector and the tower is, the higher the energy of the chimney will be.

This article deals with a study of the influence of some geometrical and physical parameters, ie the diameter of the collector and solar radiation on electric power supplied by a solar cell tower effect in south west Algeria (Beni Abbes city).

\subsection{Sizing}

\section{Presentation Of The Studied System}

Solar tower studied combines three familiar elements: a solar collector (collector), the chimney located in the center of the collector and the power conversion unit (PUC), which includes one or more generating turbines. [2] Turbines driven by the air produced buoyancy resulting from the greenhouse effect inside the collector (Fig.1).

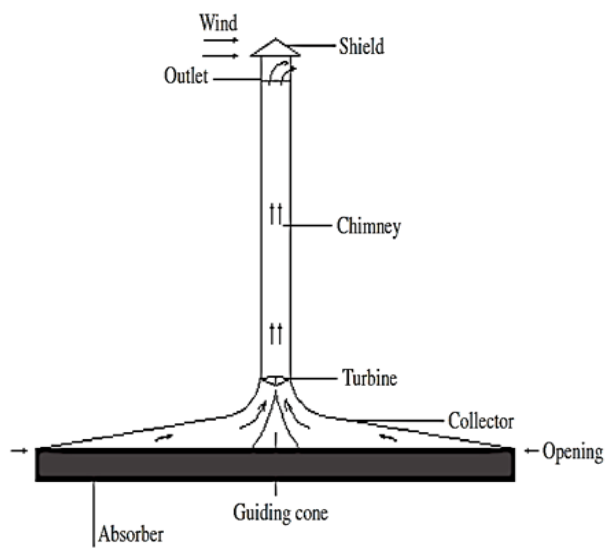

Fig.1 Geometry of the tower

The parameters that will be used in the analysis of the system performance are shown in the following table:

\begin{tabular}{|l|c|l|c|}
\hline Parameters & values & Parameters & values \\
\hline Chimney height & $450 \mathrm{~m}$ & Optical efficiency & 0.65 \\
\hline Chimney diameter & $54 \mathrm{~m}$ & Thermal conductance & $10 \mathrm{~W} / \mathrm{m}^{2 \circ} \mathrm{C}$ \\
\hline Collector diameter & 1110 & Ambient temperature & $40{ }^{\circ} \mathrm{C}$ \\
\hline Turbine efficiency & 0.8 \\
\hline
\end{tabular}

Table1 Studied System Settings

\subsection{Beni Abbes town}

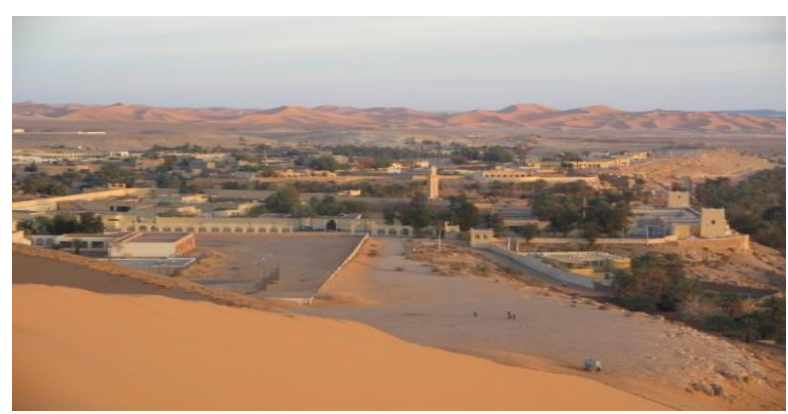

Fig.2: Beni Abbes town 
Beni Abbes is a town in the province of Bechar, located at $250 \mathrm{~km}$ southwest of Bechar and $1250 \mathrm{~km}$ south-west of Algiers. The city is built on a rocky hill on the left bank of Saoura River. It is bordered to the north, east and west by the Grand Erg Occidental and the south and southwest by the valley Saoura (Bechar).

\subsection{The electrical power of Beni Abbes}

Beni Abbes power plant is located in the industrial area at $5 \mathrm{~km}$ from the southern entrance west of downtown. Before the considerable contribution to power of two gas turbines in 2012, the power plant was still operated by diesel generators since the early 1990.[1]

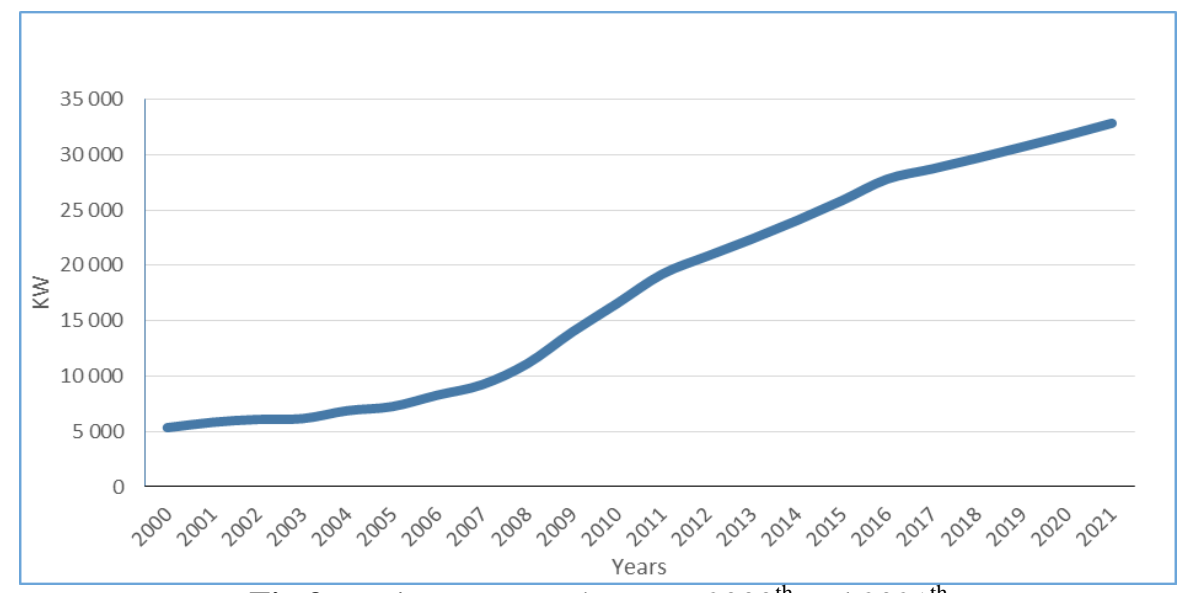

Fig.3 Maximum power between $2000^{\text {th }}$ and $2021^{\text {th }}$

\subsection{Electricity production in Beni Abbes}

The power plant of the site has a dozen diesel generators and gas turbine. In 2015, it recorded a peak power surpassing the $24 \mathrm{MW}$ and an annual consumption of $30055 \mathrm{~m}^{3}$ of fuel.[1]

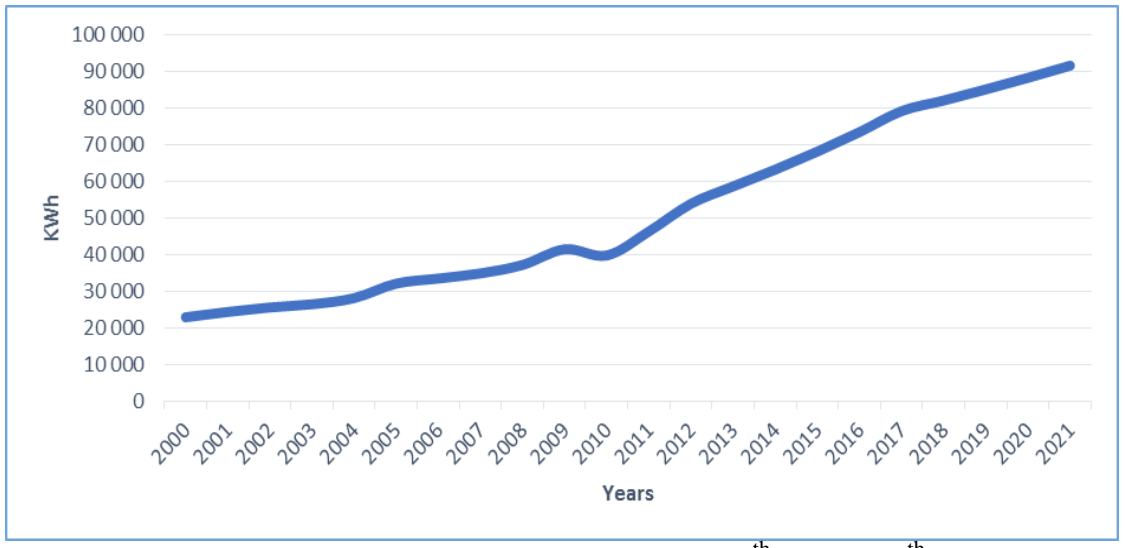

Fig.4 Electric production between $2000^{\text {th }}$ and $2021^{\text {th }}$

\subsection{Solar radiation}

\section{Materials And Methods}

Any incident radiation on earth will be broken down into several radiations. These vary depending on the height of the sun, the angle of incidence, the weather conditions and the visibility state of the atmosphere [3]. Theoretical modeling of solar radiation is very complicated due to climate variations and weather. The empirical method Perrin Brichambaut gave good results for the estimation of the energy received by a sensor in any orientation. [4] [5]. In a clear sky, the power of direct radiation and diffuse and global EG ED received by an inclined sensor $\beta$ relative to the horizontal plane are given by the following relationships:

$$
\begin{aligned}
& E_{S}=A \cdot \cos (i) \cdot \exp \left[-\frac{1}{B \cdot \sin (h+2)}\right] \\
& E_{D}=\left(\frac{1+\cos (\beta)}{2}\right) \cdot D_{H}\left(\frac{1-\cos (\beta)}{2}\right) \cdot a \cdot G_{H}
\end{aligned}
$$


With $\mathrm{A}$ is the albedo, and DH and GH are respectively the diffuse and overall on a horizontal plane given by the following two relationships:

$$
\begin{aligned}
& D_{H}=A^{\prime} \cdot(\sin (h))^{0.4} \\
& \mathrm{G}_{\mathrm{H}}=\mathrm{A}^{\prime \prime} .(\sin (\mathrm{h}))^{\mathrm{B}^{\prime}}
\end{aligned}
$$

A,A',A', et B"' are constants depends on the atmosphere stat. the following table gives the constant values for clear sky:

\begin{tabular}{|l|l|l|l|l|l|}
\hline State of the atmosphere & A & B & A' $^{\prime}$ & A $^{\prime \prime}$ & B $^{\prime \prime}$ \\
\hline Dark blue sky & 1300 & 6 & 87 & 1150 & 1.15 \\
\hline Clear blue sky & 1230 & 4 & 125 & 1080 & 1.22 \\
\hline Milky blue sky & 1200 & 2.5 & 187 & 990 & 1.25 \\
\hline
\end{tabular}

Table 2 Values of constant model Perrin Brichambaut

$\mathrm{h}$ : is the height of the sun calculated by the following formula:

$\sin (h)=\cos (\phi) \cdot \cos (\omega) \cdot \cos (\delta)+\sin (\delta) \cdot \sin (\omega)$

Where $\varphi$ is the latitude of the studied location in (Bechar $31.6^{\circ}$ ) and $\delta$ is the declination of the sun calculated by the formula:

$$
\delta=23.45 \cdot \sin \left(\frac{360}{365} \cdot(n+284)\right)
$$

$\omega$ is hour angle given by:

$$
\omega=(T S V-12) * 15
$$

Where: TSV is the true solar time

This formula is not valid for the hours of sunrise and sunset. We must therefore determine the hour angle by the following equation [6]:

$\omega_{0}=\cos ^{-1}[-\operatorname{tg}(\varphi) \cdot \operatorname{tg}(\delta)]$

Therefore the solar time at sunrise and sunset are calculated as follows:

$$
\begin{aligned}
& T S V_{L}=12-\frac{\omega_{0}}{15} \\
& T S V_{C}=12+\frac{\omega_{0}}{15}
\end{aligned}
$$

\subsection{Solar chimney}

The energy balance at the collector can be written as:

$\Phi=q \cdot C p \cdot \Delta T=\eta_{0} \cdot A_{\text {coll }} \cdot E_{G}-K \cdot \Delta T_{a} \cdot A_{\text {coll }}=\eta_{\text {coll }} \cdot E_{G}$

Where: $A_{\text {coll }}$ is the surface of the collector that receives solar radiation, $\eta_{0}$ is the product of absorbance and transmittance of the solar sensor, $\mathrm{K}$ is the overall heat loss coefficient (conductance) of the solar collector, the air density at the outlet of the solar collector is $\rho_{\text {coll. }} . \Delta \mathrm{T}_{\mathrm{a}}$ represents the temperature difference between the heat absorption layer and the ambient air; $\mathrm{q}$ is the mass flow of the hot air passing through the solar chimney calculated by the following relationship:

$$
q=\rho_{\text {coll }} \cdot A_{C} \cdot V_{c}
$$

With: $A_{c}$ is the cross section of the solar chimney, $V_{c}$ is the air velocity at the inlet of the solar chimney. According to Schlaich [7-8], the instantaneous performance of the collector is given by:

$$
\eta_{\text {coll }}=\eta_{0}-K \cdot \frac{\Delta T_{a}}{E_{G}}
$$

The values of the coefficients are respectively $\quad \eta_{0}=0.75-0.8$ and $\mathrm{K}=5-6 \mathrm{~W} / \mathrm{m}^{2} . \mathrm{K}$ for $\Delta \mathrm{Ta}=30 \mathrm{~K}[8]$.

Determining the overall conductance $\mathrm{K}$ based on the establishment of an energy balance at the collector. 


\subsection{Transparent cover}

The heat balance at the transparent cover can be written as:

$G_{c t}+h r_{a b s-c t}\left(T_{a b s}-T_{c t}\right)+h c_{c t}\left(T_{c t}-T_{m}\right)=K_{c t-a i r}\left(T_{c t}-T_{a n b}\right)$

$\mathrm{G}_{\mathrm{ct}}$ is the solar radiation absorbed by the transparent cover; $\mathrm{hr}_{\mathrm{abs}-\mathrm{ct}}$ is the heat transfer coefficient by radiation between the transparent cover and the absorber; $\mathrm{hc}_{\mathrm{ct}}$ is the heat transfer convective coefficient between the cover and the airflow through the solar collector. The overall heat loss coefficient between the transparent cover and the air-to-air $\mathrm{K}_{\mathrm{ct}}$ can be given as:

$$
K_{c t-a i r}=h_{\text {wind }}+h_{c t-s k y}
$$

$\mathrm{h}_{\text {wind }}$ is the convection coefficient of wind given by [9]:

$\mathrm{h}_{\text {wind }}=5.7+3.8 \mathrm{~V}_{\text {wind }}$

The heat transfer coefficient by radiation between the transparent cover and the sky is calculated by the following equation:

$h_{c t-c i e l}=\frac{\sigma \cdot \varepsilon_{c t}\left(T_{c t}+T_{c i e l}\right) \cdot\left(T_{c t}^{2}+T_{c i e l}^{2}\right) \cdot\left(T_{c t}-T_{c i e l}\right)}{\left(T_{c t}-T_{a m b}\right)}$

Where: $\mathrm{T}_{\text {sky }}$ is the sky temperature, given by:

$\mathrm{T}_{\text {sky }}=0.0525 .\left(\mathrm{T}_{\mathrm{amb}}\right)^{1.5}$

The heat transfer coefficient by radiation between the transparent cover and the absorber can be calculated by the following relationship:

$$
h_{c t-s k y}=\frac{\sigma \cdot\left(T_{c t}+T_{a b s}\right) \cdot\left(T_{c t}^{2}+T_{a b s}^{2}\right)}{\left(\frac{1}{\varepsilon_{a b s}}-\frac{1}{\varepsilon_{c t}}-1\right)}
$$

Where $\varepsilon_{a b s}$ and $\varepsilon_{c t}$ are respectively the emissivity of the absorber and transparent cover. $\mathrm{T}_{\mathrm{abs}}$ and $\mathrm{t}_{\mathrm{ct}}$ are respectively the temperature of the absorber and the temperature of the transparent cover.

\subsection{The absorber}

At the level of the absorber, the heat balance gives us:

$G_{a b s}=h c_{a b s}\left(T_{c t}-T_{m}\right)+h r_{a b s-c t}\left(T_{a b s}-T_{c t}\right)=K_{a b s-a i r}\left(T_{a b s}-T_{a n b}\right)$

Where $\mathrm{G}_{\mathrm{abs}}$ solar radiation absorbed by the absorber; $\mathrm{G}_{\mathrm{abs}}$ is the convective heat transfer coefficient between the absorber and the airflow through the solar collector (collector); $\mathrm{K}_{\mathrm{abs} \text {-air }}$ is the overall heat transfer coefficient between the absorber and the ground.

\subsection{The flow of air in the chimney}

The energy balance equation for the air flow in the chimney is given by:

$$
h c_{a b s}\left(T_{a b s}-T_{m}\right)+h c_{c t}\left(T_{c t}-T_{m}\right)=q \cdot C p \cdot\left(T_{a m b}-T_{0}\right)
$$

The average temperature $\mathrm{T}_{\mathrm{m}}$ is given by:

$$
T_{m}=\gamma \cdot T_{a m b}+(1-\gamma) \cdot T_{0}
$$

Hence, the equation 21 becomes:

$$
h c_{a b s}\left(T_{a b s}-T_{m}\right)+h c_{c t}\left(T_{c t}-T_{m}\right)=q \cdot C p \cdot \frac{\left(T_{m}-T_{a m b}\right)}{(1-\gamma)}
$$

$\mathrm{T}_{0}$ is the temperature of the airflow at the outlet of the manifold; $\gamma$ is a constant. Ong KS Chow and CC [10 -11] recommends a value of $\gamma=0.74$. 


\subsection{Solar Tower}

For a given solar chimney, knowing the geometrical data, the thermal conditions, one can deduce the maximum mechanical power absorbed by the turbine as follows:

$$
P_{t, \max }=\frac{2}{3} \cdot \eta_{\text {coll }} \cdot \frac{g}{C p \cdot T_{a m b}} \cdot H_{c} \cdot A_{\text {coll }} \cdot E_{G}
$$

$P_{t \text { max }}$ by multiplying by the efficiency of the turbine $\eta_{0}$, the electrical power delivered by the solar tower is then: $P_{e}=\frac{2}{3} \cdot \eta_{\text {coll }} \cdot \eta_{t} \frac{g}{C p \cdot T_{\text {amb }}} \cdot H_{c} \cdot A_{\text {coll }} \cdot E_{G}$

\section{Results and Discussion}

We present in this part of this work, the study of a solar chimney on the site of Beni Abbes, giving importance to the power developable for a day and more specifically the $21^{\text {th }}$ June (summer) and $21^{\text {th }}$ December (winter).

To do this, we developed a computer program in the MATLAB environment based on the determination of solar radiation by the empirical model Perrin Brichambaut result in the study of the influence of solar radiation and the diameter of the collector on the delivered power .

\begin{tabular}{|l|l|l|}
\hline & $21 / 06 / 2013$ & $21 / 12 / 2013$ \\
\hline Max Power & $13850 \mathrm{~kW}$ & $9300 \mathrm{~kW}$ \\
\hline Max Power & $2885 \mathrm{~kW}$ & $4200 \mathrm{~kW}$ \\
\hline Max Ambient Temp & $47^{\circ} \mathrm{C}$ & $39^{\circ} \mathrm{C}$ \\
\hline Max Ambient Temp & $31^{\circ} \mathrm{C}$ & $19^{\circ} \mathrm{C}$ \\
\hline AvrageTemp/Jr & $40^{\circ} \mathrm{C}$ & $30^{\circ} \mathrm{C}$ \\
\hline
\end{tabular}

Table 3 Data days of 21/06 and 21/12 year 2013

\subsection{Effect of solar illumination}

Figures 5 and 6 shows the evolution of the daily solar irradiance on a horizontal plane and the power supplied by the solar tower to the same day in both periods chosen. First place we see that solar irradiation and power produced have the same allure.

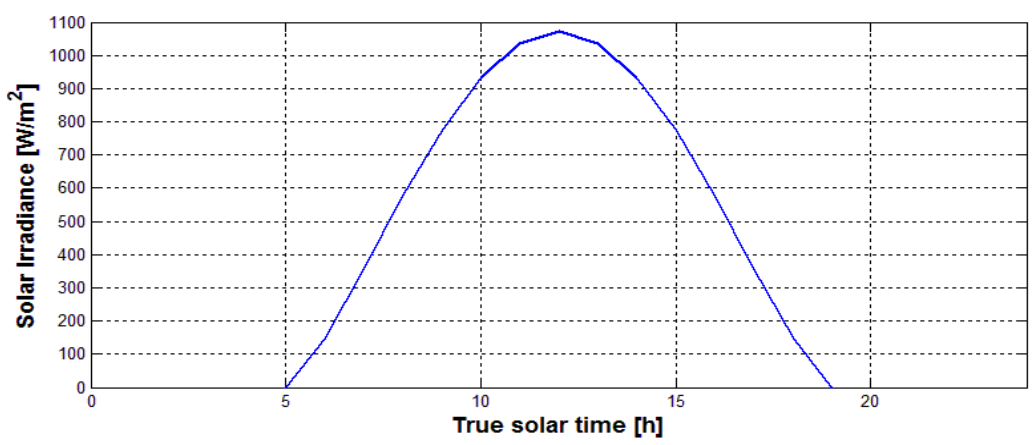

Fig.5 Evolution of daily solar illumination for the month of June

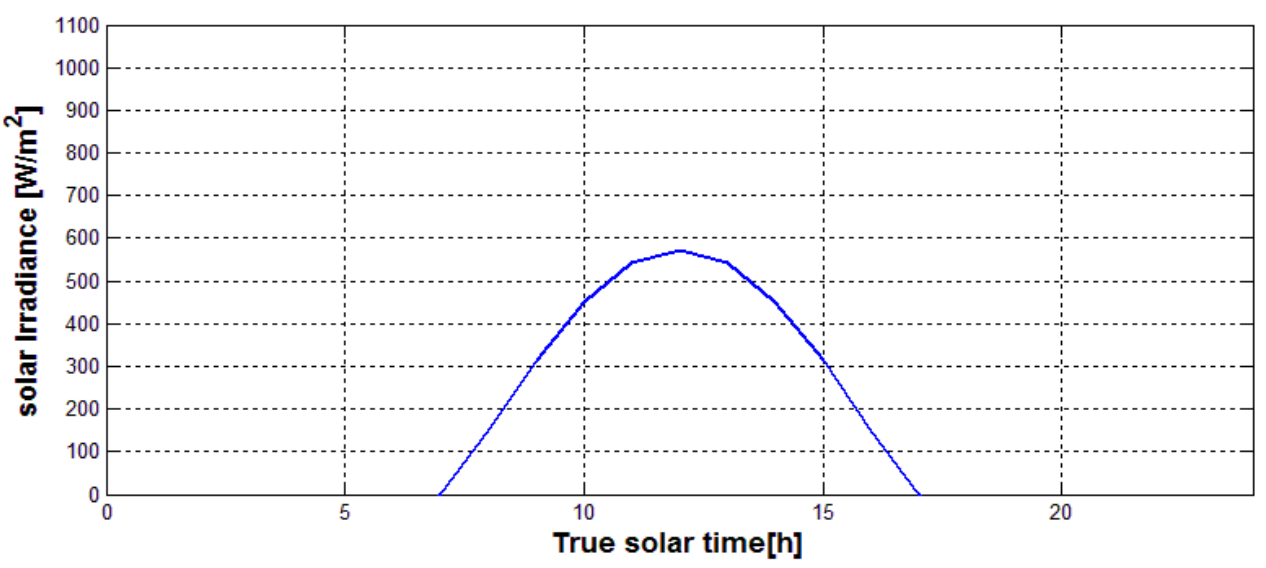

Fig.6 Evolution of daily solar illumination for the month of December 
From the above figures and a clear sky, we notice that solar radiation varies throughout the day in a Gaussian manner. It is low in the vicinity of sunrise and sunset which corresponds to zero sun height and reaches the maximum in the middle of the day that is to say at solar noon when the Sun is up.

Figures 7 and 8 shows the power delivered to the two selected days, we note that the developable capacity is much higher of June until December, since solar illumination received at the collector is very high in this month. In June, the city of Beni Abbes receives a considerable amount of solar radiation, the peak radiation appears at noon is roughly of the order of $1071 \mathrm{~W} / \mathrm{m}^{2}$ corresponding to a power exceeding the level of 5000 while in KW December luminance peak is of the order of $774 \mathrm{~W} / \mathrm{m}^{2}$ which is a developable power exceeding the level of $3000 \mathrm{KW}$. This results lead to the conclusion that the system efficiency is important during the summer.

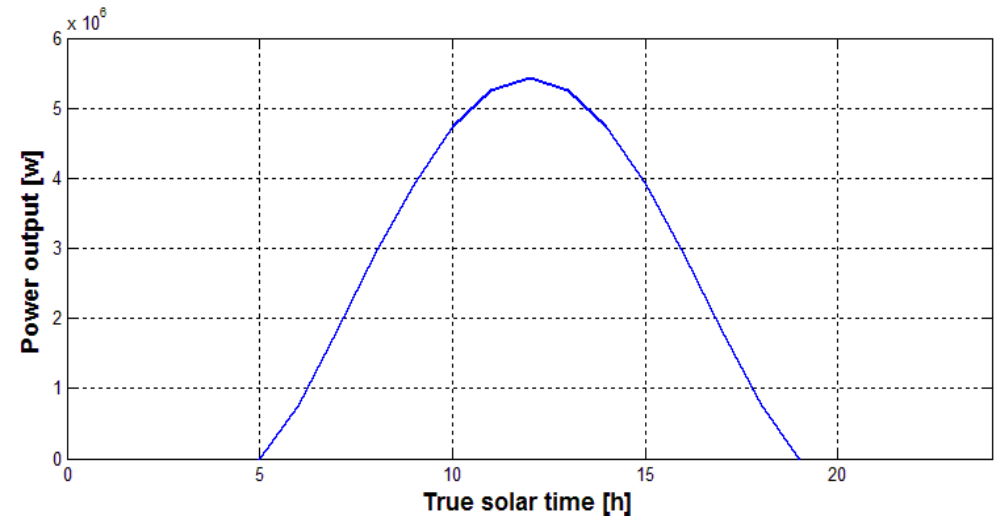

Fig.7 Power produced the daily June.

$\mathrm{H}_{\text {Chem }}=450 \mathrm{~m}, \mathrm{D}_{\text {coll }}=1110 \mathrm{~m}$

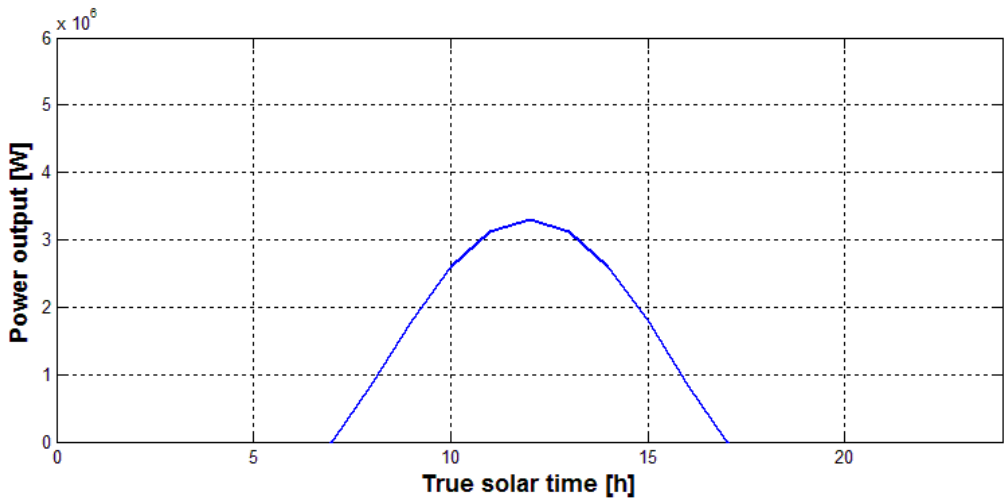

Fig.8 Power produced daily December

$\mathrm{H}_{\text {Chem }}=450 \mathrm{~m}, \mathrm{D}_{\text {coll }}=1110 \mathrm{~m}$

\subsection{Effect of the collector diameter}

Figure 9 shows the evolution of the daily power generated by solar tower for different diameters of the manifold. There is an increase of the power generated with the increase in diameter of the solar collector (collector). Almost $40 \mathrm{MW}$ of electrical power can be developed by a tower having a collector diameter of $3000 \mathrm{~m}$. It can also improve power production by increasing the height of the chimney.

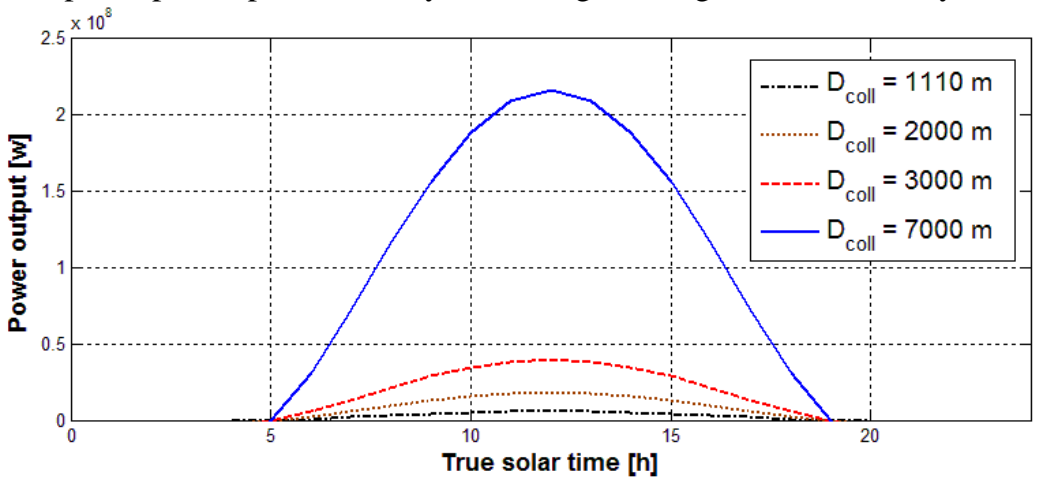

Fig.9 developable power for different diameters

of the collector, $\mathrm{H}_{\text {Chem }}=450 \mathrm{~m}$, June 21, 2013 


\subsection{Cross-media effect of the diameter of the collector chimney height}

Figure 10 shows the influence of the cross diameter of the collector and the height of the chimney. One constant in the first place that the tower has an output of about $35 \mathrm{MW}$ for the same value of the diameter of the collector and the chimney height $(2700 \mathrm{~m})$. Beyond $2700 \mathrm{~m}$, the effect of manifold diameter is very dominant and therefore the tower can deliver a power of $110 \mathrm{MW}$ with a diameter of $5000 \mathrm{~m}$, while the latter is of the order of $60 \mathrm{MW}$ for the same value of the height of the chimney. Below $2700 \mathrm{~m}$ the effect of the height of the chimney is dominant over the diameter of the collector.

We can conclude that for reasons of cost of realization and design and to have better performance, it will be better to play on the collector surface.

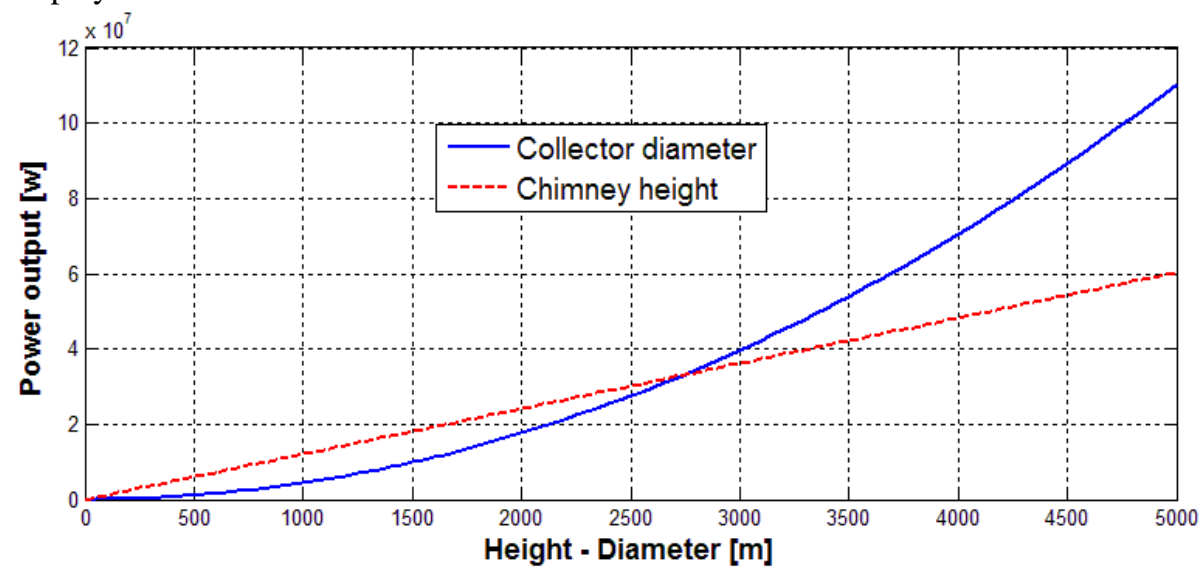

Fig.10 Effect crossover diameter and height

$\mathrm{EG}=1071 \mathrm{~W} / \mathrm{m}^{2}$

\section{Conclusion}

Recall that the main characteristics of a solar tower stack effect is the solar collector (collector) and chimney. Solar radiation heats the earth, which in turn heats the air under the collector. The warm air rises and escapes through the chimney. The airflow with high temperature resulting is used to generate electricity through one or more turbine generators. The power produced from solar radiation depends on the height of the chimney and the collector surface.

Power generation increases with increasing stack height and the surface of the collector. It is also noted that more solar illumination, the power generation will be great.

Solar tower in our study can develop a 5.5 MW power in single turbine. Its geometry allows having more than one turbine and thus achieving a very important power generation enough to meet the electricity needs of the population in favor of the considered site. The solar collector can also act as greenhouse horticulture for agricultural purposes, which will indirectly help in reducing the cost per kilowatt hour produced.

\section{References}

[1]. Document prepared by the Directorate General of Strategy and Prospective Sonelgaz Group (May 2011)

[2]. Xinping Zhou, Fang Wang, Reccab Mr Ochieng. 2010. A review of solar chimney power technology. Renewable and Sustainable

[3]. Energy Reviews 14, 2315-2338

[4]. Perrin. De Brichambaut 1984. Evaluation of a solar energy field and Tec Doc

[5]. Zidani C., F. and B. Benyarou Benyoucef, 2003. Simulations of the apparent position of the sun and solar energy estimate incident on photovoltaic flat collector for the city of Tlemcen (Algeria). Review renewables Vol.6, 69-76.

[6]. Maouedj Rachid, 2005. Application of photovoltaics to the hydraulic pump on the sites of Tlemcen and Bouzareah. Magister From memory, University Abu Bekr Belkaïd. Tlemcen

[7]. Jacques Bernard, 2004. Solar energy, calculation and optimization. - Energy engineering. Ellipses Edition-254

[8]. J Schlaich, 1995. The solar chimney: electricity from the sun. Geislingen: Maurer C; pp. 55.

[9]. Nizetic S., B. Klarin., 2010. A simplified analytical approach for assessment of the optimal ratio of pressure drop across the turbine in solar chimney power plants. Applied Energy 87, 587-591.

[10]. DUFFIE. J.A and BECKMAN.W.A., 1974. Solar energy thermal processes. Wiley Interscience New York.

[11]. Ong KA, Chow CC, 2003. Performance of solar chimney. Solar Energy 74, 1-17.

[12]. M. Maerefat, A.P. Haghighi., 2010. Passive cooling of buildings by using integrated earth to air heat exchanger and solar chimney. Renewable Energy 35 2316-2324. 